\title{
Tolbutamide reduces the incidence of diabetes mellitus, but not insulitis, in the non-obese-diabetic mouse
}

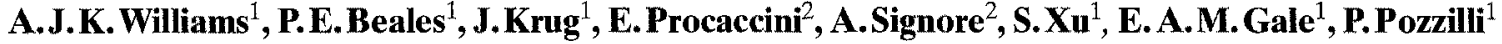 \\ ${ }^{1}$ Department of Diabetes and Metabolism, St. Bartholomew's Hospital Medical College, London, UK \\ ${ }^{2}$ Department of Endocrinology, II Clinica Medica, University of Rome 'La Sapienza', Rome, Italy
}

\begin{abstract}
Summary. The functional state of beta cells may influence the rate of their destruction in Type 1 (insulin-dependent) diabetes mellitus. We examined the effect of diazoxide, which inhibits insulin secretion, or tolbutamide, which stimulates insulin secretion, upon the incidence of diabetes in the non-obese-diabetic (NOD) mouse. Female mice were treated from 3-30 weeks of age with diet containing diazoxide $250 \mathrm{mg} \cdot \mathrm{kg}^{-1}$ or tolbutamide $125 \mathrm{mg} \cdot \mathrm{kg}^{-1}$. The cumulative incidence of diabetes at 35 weeks was similar in the diazoxide (16 of 24) and control (18 of 24) groups, but reduced in the tolbutamide group ( 10 of $23, p<0.04$ vs control group). In a second experiment, treatment was started from 9 weeks of age, by which time insulitis is already present. The cumulative incidence of diabetes at 35 weeks was 16 of 24 in controls, 15 of 24 on diazoxide and 11 of 24 on tolbutamide ( $p=$ NS vs control). A third experiment compared the effect of treat-
\end{abstract}

ment from 3 weeks with control diet or diet containing tolbutamide $125 \mathrm{mg} \cdot \mathrm{kg}^{-1}$ or $500 \mathrm{mg} \cdot \mathrm{kg}^{-1}$. Diabetes was reduced by tolbutamide treatment, with a cumulative incidence of 25 of 31 in controls, 18 of 30 on tolbutamide $125 \mathrm{mg} \cdot \mathrm{kg}^{-1}$ $(p<0.04)$ and 14 of 32 on $500 \mathrm{mg} \cdot \mathrm{kg}^{-1}(p<0.002)$, although the difference between the two treatment groups failed to reach statistical significance. A fourth experiment showed that treatment from $3-12$ weeks with diazoxide $1000 \mathrm{mg} \cdot \mathrm{kg}^{-1}$ increased the extent of insulitis compared with controls and animals treated with tolbutamide $500 \mathrm{mg} \cdot \mathrm{kg}^{-1}$. Elucidation of the mechansims by which tolbutamide reduces the incidence of diabetes in the NOD mouse has implications for human intervention trials.

Key words: NOD mouse, tolbutamide, diazoxide, Type 1 (insulin-dependent) diabetes mellitus
Prophylactic insulin therapy has been found to reduce the incidence of diabetes mellitus in two spontaneous animal models of Type 1 (insulin-dependent) diabetes, the BioBreeding (BB) Wistar rat $[1,2]$ and the non-obesediabetic (NOD) mouse [3]. In order to explain these findings, it was proposed that "a reduction of endogenous insulin secretion might reduce beta-cell antigen expression to such a level that the autoimmune cascade is not initiated or is alleviated" [1]. Furthermore, a trial of intensive insulin therapy in newly-diagnosed Type 1 diabetic patients concluded that suppression of endogenous insulin may improve beta-cell function over the subsequent year [4].

These observations have prompted clinical trials of prophylactic insulin therapy in islet cell antibody-positive non-diabetic subjects, in an attempt to protect beta cells from autoimmune destruction [5]. Since insulin requires repeated injection, oral agents also deserve consideration.
We have examined whether tolbutamide and diazoxide, drugs which modify insulin secretion, affect the incidence of diabetes in the NOD mouse. Both drugs are thought to act via the ATP-sensitive potassium channel of beta cells [6]. Tolbutamide closes this channel causing stimulation of insulin secretion, whereas diazoxide opens the channel leading to inhibition of insulin secretion. By exploiting the opposing effects of these drugs, we set out to clarify whether the functional state of the beta cells influences the rate of their destruction in Type 1 diabetes.

Our initial experiment showed that prophylactic tolbutamide treatment reduced the cumulative incidence of diabetes in the NOD mouse [7]. Diazoxide, on the other hand, did not significantly alter the incidence of diabetes. These findings challenged the belief that suppression of endogenous insulin secretion may protect the beta cells from destruction. We therefore performed a further series of experiments in order to confirm and to extend our original observations. 


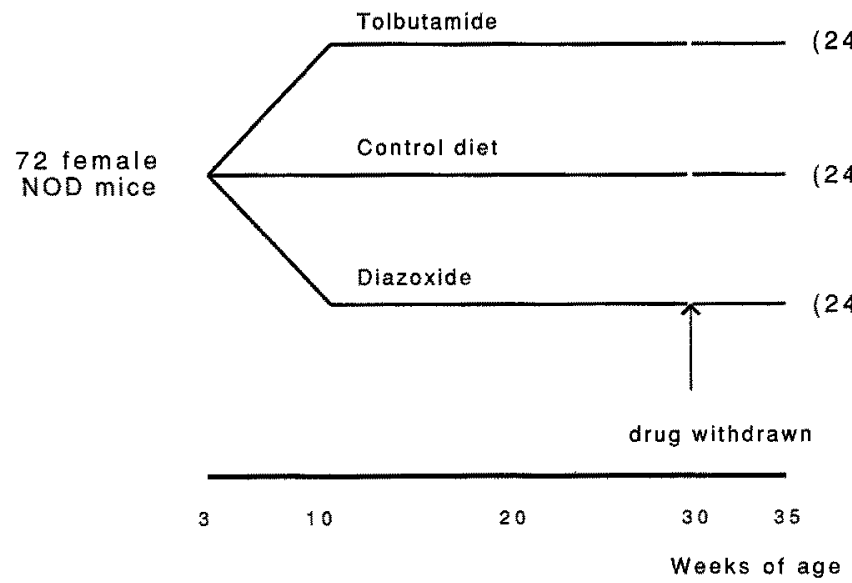

Fig. 1. The protocol for investigating the effect of either $250 \mathrm{mg}$. $\mathrm{kg}^{-1}$ diazoxide or $125 \mathrm{mg} \cdot \mathrm{kg}^{-1}$ tolbutamide in the diet, on the incidence of diabetes in the NOD mouse

\section{Materials and methods}

\section{Development of diabetes}

\section{Experiment 1}

The first experiment investigated the effect of prophylactic diazoxide or tolbutamide treatment from 3 weeks of age, on the development of diabetes in the NOD mouse. Seventy-two female NOD mice were split into three litter-matched groups at 3 weeks of age and given either a control diet, diet containing diazoxide $\left(250 \mathrm{mg} \cdot \mathrm{kg}^{-1}\right)$ or diet containing tolbutamide $\left(125 \mathrm{mg} \cdot \mathrm{kg}^{-1}\right)$. Therapy was withdrawn at 30 weeks of age and the animals followed-up for a further 5 weeks (Fig. 1) to ensure that the hypoglycaemic effect of tolbutamide did not mask occult diabetes and to reveal the long-term effects of treatment. The mice were weighed weekly from the start of therapy and tested weekly for glycosuria from 10 weeks of age, with diabetes being diagnosed on finding a urine glucose level greater than $56 \mathrm{mmol} / \mathrm{l}$ on more than one occasion (Diabur-Test 5000 ; Boehringer Mannheim, Mannheim, FRG). The animals were killed at 35 weeks of age or when diabetes was confirmed and the pancreata were then frozen for histological investigation.

\section{Experiment 2}

Therapies aimed at preventing the onset of Type 1 diabetes in humans, require the identification of individuals at high risk of developing the disease. Since the presence of islet cell antibodies gives the best prediction of disease, therapeutic intervention may only be attempted when the autoimmune process is already underway [8]. A further 72 female mice were therefore treated according to the same protocol, but with therapy started at 9 weeks of age, to determine whether tolbutamide could reduce the incidence of diabetes, even when insulitis is already present [9].

\section{Experiment 3}

A third experiment was performed to determine whether a further reduction in diabetes incidence could be obtained, by increasing the dose of tolbutamide. Ninety-six female NOD mice were split into three litter-matched groups and treated from 3 weeks of age with either control diet, or diet containing either $125 \mathrm{mg} \cdot \mathrm{kg}^{-1}$ or $500 \mathrm{mg} \cdot \mathrm{kg}^{-1}$ tolbutamide. Animals were monitored for diabetes from 10 weeks of age, the drug was withdrawn at 30 weeks, the mice were killed at 31 weeks of age and the pancreata frozen for histological investigation.

\section{Insulitis and metabolic studies}

\section{Experiments 4 and 5}

Two further experiments were performed in order to discover whether the drug treatment altered the progression of insulitis and influenced glucose metabolism. Seventy-two litter-matched female NOD mice were treated from 3 weeks of age according to the same protocol with control diet, $500 \mathrm{mg} \cdot \mathrm{kg}^{-1}$ tolbutamide or $1000 \mathrm{mg} \cdot \mathrm{kg}^{-1}$ diazoxide. At 12 weeks of age a basal blood glucose sample was collected immediately after food was withdrawn. An intraperitoneal glucose load ( $2 \mathrm{~g} / \mathrm{kg}$ body weight) was administered and a further sample obtained, at either 30 or $60 \mathrm{~min}$, for blood glucose and serum insulin measurements. The mice were killed and the pancreata frozen for histological investigation. A further 48 littermatched female NOD mice were treated according to the same protocol but killed at 8 weeks of age, $30 \mathrm{~min}$ after a glucose load with blood being taken for glucose and insulin measurements.

\section{Pancreatic insulin content}

\section{Experiment 6}

Pancreatic immunoreactive insulin (IRI) content was measured in order to determine the possible effects of treatment on beta-cell mass or granulation. Twenty-four litter-matched female and 24 litter-matched male NOD mice were treated according to the same protocol with control diet, $250 \mathrm{mg} \cdot \mathrm{kg}^{-1}$ diazoxide or $125 \mathrm{mg} \cdot \mathrm{kg}^{-1}$ tolbutamide from 3 weeks of age. At 11 weeks of age the mice were killed and the pancreata removed, frozen and stored at $-70^{\circ} \mathrm{C}$ until extraction.

\section{Mouse colony}

The NOD mice used in these experiments were obtained from the breeding colony at St.Bartholomew's Hospital, which was established in 1987 and derived originally from the colony of Dr. E. Leiter (Jackson Laboratory, Bar Harbor, Me., USA). The mice are kept in a conventional unit and the colony maintained by parallel line inbreeding. The colony is characterised by the onset of insulitis at 3-5 weeks of age and the onset of diabetes from approximately 10 weeks of age [10].

\section{Treatment}

Diazoxide (gift of Schering Plough, Mildenhall, Suffolk, UK) or tolbutamide (Sigma, Poole, Dorset, UK) were given as an admixture in a standard rodent diet (Quest Nutrition, Wingham, Kent, UK).

\section{Blood glucose and serum insulin measurements}

Blood glucose was measured by a glucose oxidase method (Yellow Springs Instruments, Yellow Springs, Ohio, USA). Serum insulin was determined using a double-antibody radioimmunoassay [11] with guinea-pig anti-human insulin first antibody (in house) and sheep anti-guinea pig $F_{c}$ (International Laboratory Service, London, UK) as the second antibody. ${ }^{125}$-labelled human insulin (Amersham International, Amersham, Bucks, UK) was used as tracer, with human insulin standards (Novo Biolabs, Bagsvaerd, Denmark). 


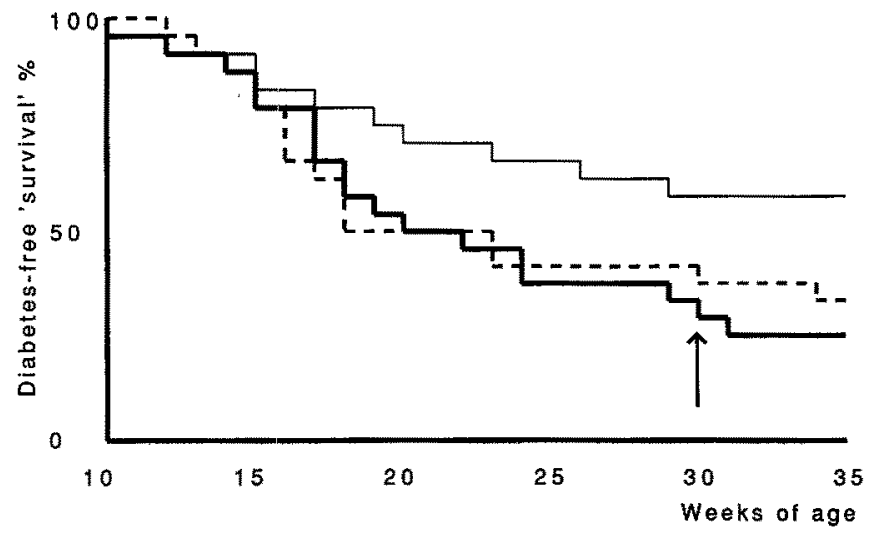

Fig. 2. The cumulative incidence of diabetes in female NOD mice treated from weaning with control diet (bold line) or diet containing either $250 \mathrm{mg} \cdot \mathrm{kg}^{-1}$ diazoxide (dotted line) or $125 \mathrm{mg} \cdot \mathrm{kg}^{-1}$ tolbutamide (fine line). The incidence of diabetes in tolbutamide-treated animals was significantly less than control $(p<0.04)$. The age at which therapy was withdrawn is denoted by an arrow

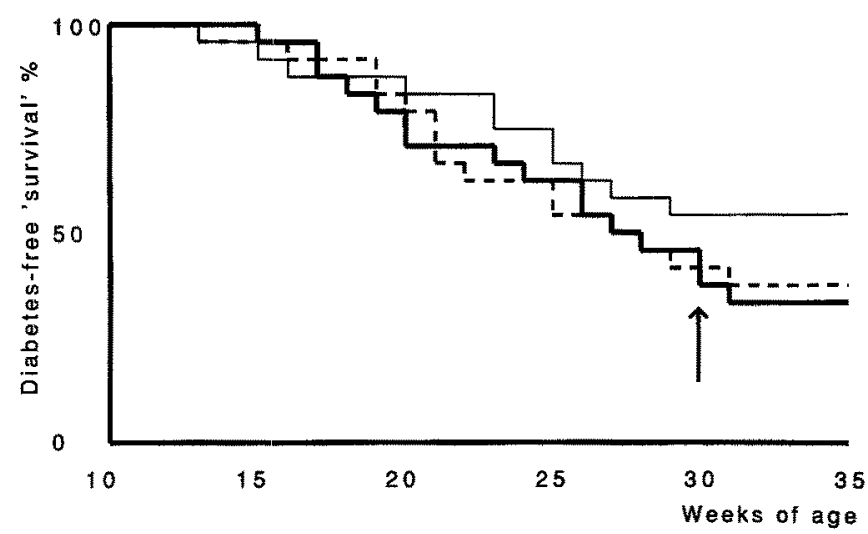

Fig. 3. The cumulative incidence of diabetes in female NOD mice treated from 9 weeks of age with control diet (bold line) or diet containing either $250 \mathrm{mg} \cdot \mathrm{kg}^{-1}$ diazoxide (dotted line) or $125 \mathrm{mg} \cdot \mathrm{kg}^{-1}$ tolbutamide (fine line). There were no significant differences in the incidence of diabetes between the different treatment groups. The age at which therapy was withdrawn is denoted by an arrow

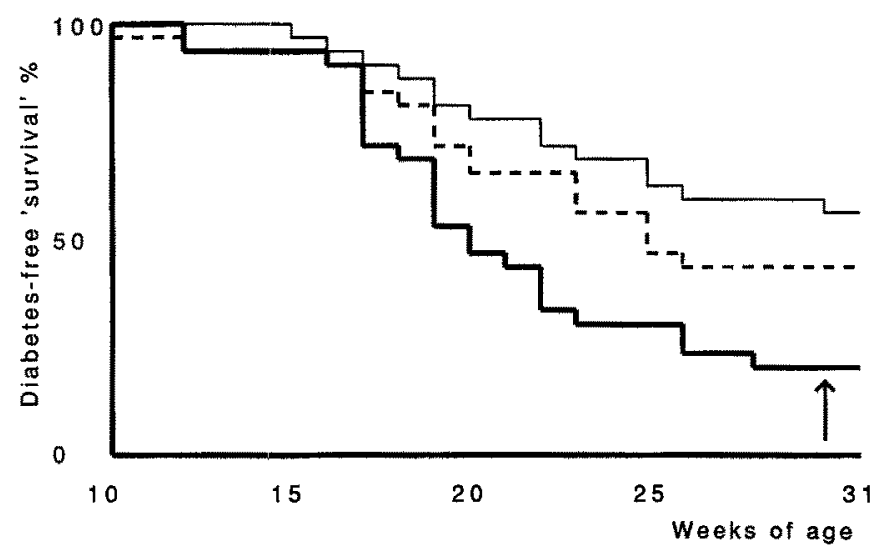

Fig.4. The cumulative incidence of diabetes in female NOD mice treated from 3 weeks of age with control diet (bold line) or diet containing either $125 \mathrm{mg} \cdot \mathrm{kg}^{-1}$ (dotted line) or $500 \mathrm{mg} \cdot \mathrm{kg}^{-1}$ tolbutamide (fine line). The incidence of diabetes was significantly less than control in both the $125 \mathrm{mg} \cdot \mathrm{kg}^{-1} \quad(p<0.04)$ and $500 \mathrm{mg} \cdot \mathrm{kg}^{-1}$ $(p<0.002)$ tolbutamide-treated groups. The age at which therapy was withdrawn is denoted by an arrow

\section{Histology}

Ten $6 \mu \mathrm{m}$ frozen sections were cut at $200 \mu \mathrm{m}$ intervals from each pancreas, mounted on glass slides and stained with haemotoxylin and eosin. The sections were assessed 'blind' for insulitis, with the islets being classified according to the severity of lymphocytic infiltration (uninfiltrated, peri-insulitis $=<10 \%$ of islet area infiltrated, moderate $=<50 \%$ of islet area infiltrated, severe $=>50 \%$ of islet area in filtrated). The percentage of islets falling within each classification was then calculated for each mouse.

\section{Immunoreactive insulin (IRI) extraction}

After weighing, pancreata were hand-homogenized in $4 \mathrm{ml}$ of icecold $0.1 \mathrm{~mol} / 1 \mathrm{HCl}$ containing enzyme inhibitors $(2 \mathrm{mmol} / \mathrm{l} \mathrm{p}-\mathrm{Hy}$ droxymercuribenzoate, $2 \mathrm{mmol} / \mathrm{l}$ EDTA, $2 \mathrm{mmol} / \mathrm{l} \mathrm{N}$-Ethylmaleimide). A total of $200 \mu \mathrm{l}$ of phenylmethylsulphonyl fluoride $(2 \mathrm{mmol} / \mathrm{l})$ in methanol was added in $50 \mu \mathrm{l}$ aliquots during the extraction, in order to inactivate serine proteases. The extracts were centrifuged $\left(2500 \mathrm{~g}\right.$ at $4^{\circ} \mathrm{C}$ for $1 \mathrm{~h}$ ), and the supernatants stored at $-70^{\circ} \mathrm{C}$ until assayed. After dilution in assay buffer, insulin in the supernatants was measured by radioimmunoassay as described previously, but with rat insulin standards (Novo Biolabs). Dilutions of the extracts were shown to be parallel with the standard curve and in three different experiments using immunoprecipitation with insulin antibody, recovery of ${ }^{125} \mathrm{I}$-labelled insulin added during extraction was $81 \%, 69 \%$ and $65 \%$.

\section{Statistical analysis}

Lifetable analysis, with the logrank test, was used to compare the cumulative incidence data [12]. Animals dying from causes unrelated to diabetes were counted as censored observations. Body weights, insulitis, blood glucose, serum insulin levels and pancreatic insulin contents of the different groups were compared using the KruskalWallis test. If a significant result was obtained using the KruskalWallis test, differences between the groups were analysed using the Mann-Whitney U test. Two-tailed tests were used for comparison between groups.

\section{Results}

\section{Diabetes outcome}

\section{Experiment 1}

The effects of treatment from 3 weeks of age on diabetes incidence are shown in Figure 2. At 35 weeks of age, 10 of 23 animals in the tolbutamide-treated group had developed diabetes compared with 18 of 24 in the control $(p<0.04)$ and 16 of 24 in the diazoxide-treated ( $p=$ NS) groups. There were no significant differences between the groups in either the extent or severity of insulitis in nondiabetic survivors at 35 weeks of age (data not shown).

\section{Experiment 2}

The effects of treatment from 9 weeks of age on diabetes incidence are shown in Figure 3. At 35 weeks, 11 of 24 animals in the tolbutamide-treated group had developed diabetes compared with 16 of 24 in the control $(p=\mathrm{NS})$ and 15 of 24 in the diazoxide-treated ( $p=$ NS) groups. 


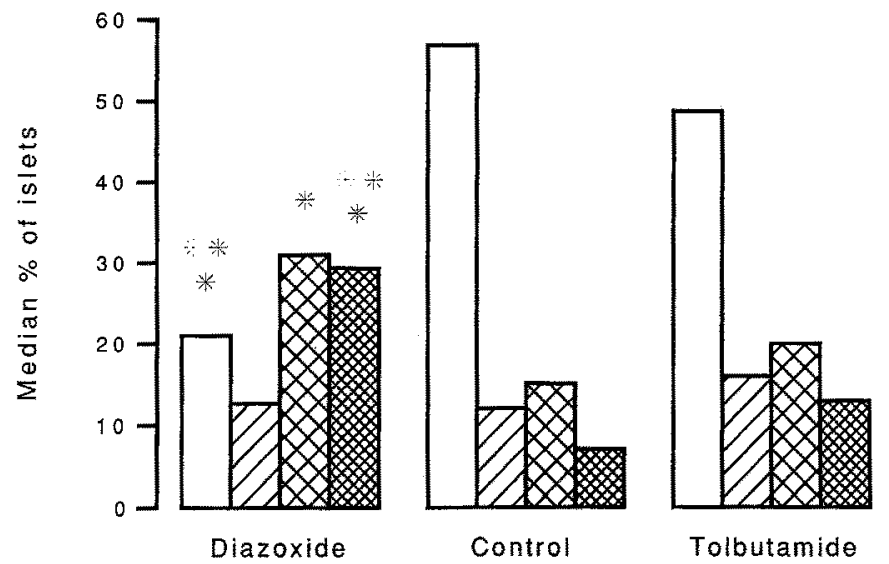

Fig.5. Insulitis in female NOD mice at 12 weeks of age, following treatment from weaning with diet containing either $1000 \mathrm{mg} \cdot \mathrm{kg}^{-1}$ diazoxide or $500 \mathrm{mg} \cdot \mathrm{kg}^{-1}$ tolbutamide. Islets are classified according to the severity of lymphocytic infiltration (uninfiltrated $\square$, periinsulitis $=<10 \%$ of islet area infiltrated $\square$, moderate $=<50 \%$ islet area infiltrated severe $=>50 \%$ of islet area infiltrated , significant differences $(p<0.05)$ are indicated: " diazoxide vs control, * diazoxide vs tolbutamide

\section{Experiment 3}

Treatment from 3 weeks of age with $125 \mathrm{mg} \cdot \mathrm{kg}^{-1}$ tolbutamide in the diet caused a significant reduction in diabetes incidence when compared to control(18 of 30 vs 25 of 31 , $p<0.04)$ and a further reduction was observed when the dosage of tolbutamide was increased to $500 \mathrm{mg} \cdot \mathrm{kg}^{-1}(14$ of $32, p<0.002$ vs control) (Fig.4), although the difference between the two doses was not significant. There were no significant differences in either the extent or severity of insulitis in non-diabetic survivors at 31 weeks of age (data not shown).

\section{Histology and metabolic status}

Experiments 4 and 5

The mean number of islets investigated in each mouse at 12 weeks of age was 127 with a minimum of 52 . The degree and severity of insulitis in the three groups at this age is illustrated in Figure 5. The diazoxide-treated group had a significantly lower percentage of uninfiltrated islets than the control group (Median 21, range $0-100 \%$ vs 57 , $4-98 \%, p<0.05)$ and the tolbutamide-treated group (49, $1-94 \%, p<0.05)$. The diazoxide-treated animals also had a significantly higher percentage of moderately infiltrated islets $(31,0-39 \%)$ than the control group $(15,0-35 \%$, $p<0.02)$ and a significantly higher percentage of severely infiltrated islets $(29,0-65 \%)$ than either the control $(7,0$ $54 \%, p<0.03)$ or tolbutamide-treated $(13,1-53 \%$, $p<0.04)$ groups. There were no significant differences between the control and tolbutamide-treated animals, in either the extent or severity of insulitis.

Basal and stimulated blood glucose levels and stimulated serum insulin levels are shown in Table 1. There were no significant differences between the groups in basal and stimulated blood glucose levels or stimulated insulin levels at either 8 or 12 weeks of age.
Table 1. Blood glucose and serum insulin results of NOD mice treated with diet containing either $1000 \mathrm{mg} \cdot \mathrm{kg}^{-1}$ diazoxide or $500 \mathrm{mg} \cdot \mathrm{kg}^{-1}$ tolbutamide, before and after a $2 \mathrm{~g} / \mathrm{kg}$ glucose load. Serum insulin was measured using human insulin standards. There were no significant differences between the treatment groups

\begin{tabular}{|c|c|c|c|c|}
\hline \multirow[b]{2}{*}{ Treatment } & \multirow{2}{*}{$\begin{array}{l}\text { Age } \\
\text { (weeks) }\end{array}$} & \multicolumn{2}{|c|}{ Glucose $(\mathrm{mmol} / \mathrm{)})$} & \multirow{2}{*}{$\begin{array}{l}\text { Insulin } \\
(\mathrm{pmol} / \mathrm{l}) \\
30 \mathrm{~min}\end{array}$} \\
\hline & & Basal & $30 \mathrm{~min}$ & \\
\hline$\overline{\text { Diazoxide }}$ & 8 & $4.9(4.1-5.4)$ & $6.1(4.2-17.8)$ & $141(66-198)$ \\
\hline Control & 8 & $4.7(3.9-5.3)$ & $6.1(4.5-8.4)$ & $132(102-378)$ \\
\hline Tolbutamide & 8 & $5.1(3.8-6.6)$ & $6.6(5.4-8.8)$ & $186(96-264)$ \\
\hline Diazoxide & 12 & $4.6(3.7-5.3)$ & $5.7(4.5-8.7)$ & $90 \quad(42-144)$ \\
\hline Control & 12 & $4.9(4.4-5.4)$ & $6.0(4.9-14.3)$ & $144 \quad(96-270)$ \\
\hline \multirow[t]{2}{*}{ Tolbutamide } & 12 & $4.7(3.8-5.6)$ & $6.4(4.6-11.0)$ & $90(66-126)$ \\
\hline & & Basal & $60 \mathrm{~min}$ & $60 \mathrm{~min}$ \\
\hline Diazoxide & 12 & $4.1(3.0-5.7)$ & $4.4(3.5-9.0)$ & $81(30-204)$ \\
\hline Control & 12 & $4.0(3.5-4.8)$ & $4.6(3.1-5.6)$ & $81(48-1200)$ \\
\hline Tolbutamide & 12 & $4.2(3.3-8.4)$ & $4.8(3.9-5.9)$ & $99(42-438)$ \\
\hline
\end{tabular}

Values are medians with ranges in brackets

\section{Pancreatic IRI content}

\section{Experiment 6}

There were no significant differences in the extractable IRI content of the pancreata of either male (control $=$ median 23 , range $19-34 \mathrm{nmol} / \mathrm{g}$, diazoxide $=24$, $19-31 \mathrm{nmol} / \mathrm{g}, \quad$ tolbutamide $=23, \quad 20-32 \mathrm{nmol} / \mathrm{g}$ ) or female (control $=29,25-41 \mathrm{nmol} / \mathrm{g}$, diazoxide $=29,14$ $39 \mathrm{nmol} / \mathrm{g}$, tolbutamide $=36,21-60 \mathrm{nmol} / \mathrm{g}$ ) mice.

\section{Body weights}

There were no significant differences between any of the treatment groups in the incremental area for body weight of animals, from 3-8 weeks of age (data not shown).

\section{Discussion}

This study shows that prophylactic tolbutamide treatment from weaning consistently reduces the incidence of diabetes in the NOD mouse. The reduction in diabetes incidence is not accompanied by a reduction in either the extent or severity of insulitis at 12 weeks of age, indicating that the initial stages of the autoimmune process are not affected. When tolbutamide treatment was started at 9 weeks of age however, the reduction in diabetes incidence did not reach statistical significance. The failure to reach significance could be due to an insufficient sample size or may indicate that early intervention is important, if tolbutamide is to be effective in preventing diabetes.

Diazoxide at $1000 \mathrm{mg} \cdot \mathrm{kg}^{-1}$ was found to increase the degree of insulitis in the NOD mouse at 12 weeks of age, but did not significantly alter the incidence of diabetes at a dose of $250 \mathrm{mg} \cdot \mathrm{kg}^{-1}$. This discrepancy may be due to the different dosages of drug used for the investigation of diabetes incidence and insulitis. These findings however, contrast with those of a previous study performed in $\mathrm{BB}$ rats, in which diazoxide significantly reduced the in- 
cidence of diabetes [13]. The different outcomes of the experiments in mice and rats may be explained by the different effects of diazoxide treatment on insulin secretion, since temporary hyperglycaemia was observed in the rats but not in the mice.

There were no significant differences between the treatment groups in blood glucose or insulin levels at either 8 or 12 weeks of age. No hypoglycaemic effects of tolbutamide were found, nor were significant hyperglycaemic effects of diazoxide treatment observed. Both treatment groups however, tended to have lower 30-min insulin levels at 12 weeks of age than the control group, even though the blood glucose levels were very similar. These findings suggest that peripheral insulin sensitivity may be increased in the treated animals, an effect of sulphonylurea treatment which has previously been observed [14-16]. Since diabetes in NOD mice is characterized by a state of insulinopenia and insulin resistance [17], an increase in insulin sensitivity could lead to a reduction in diabetes incidence.

The success of prophylactic insulin therapy $[1,2,3,18]$ in reducing the incidence of diabetes in BB rats and NOD mice has been attributed to a reduction in beta-cell autoantigen expression. In support of this hypothesis, it has been shown that expression of a beta-cell surface antigen is reduced upon fasting or after insulin treatment [19]. This mechanism is unlikely to explain our findings however, since tolbutamide reduces the incidence of diabetes but does not cause significant alterations in either insulitis or pancreatic IRI content. Unlike insulin [20], tolbutamide is unlikely to act as a foreign antigenic stimulus, although the drug may have a suppressive effect on lymphocyte beta-cell cytotoxicity. Indeed, another sulphonylurea, glipizide, was shown to reduce the incidence of diabetes in $\mathrm{BB}$ rats and to have immunosuppressive properties in vitro [21].

There were no significant differences in insulitis between the groups of non-diabetic survivors from either experiment 1 or experiment 3 . Although these observations were made after withdrawal of the drugs and few control animals survived, they indicate that the autoimmune process is not reversed by prolonged treatment with tolbutamide. The fact that few tolbutamide-treated animals became diabetic after withdrawal of the drug, could mean that these mice have passed through the phase of high disease susceptibility. In this context, it has been shown in rats that islet-cell mass increases [22] and immunological activity decreases with age [23].

A beta-cell trophic action of tolbutamide both in vivo [24] and in vitro [25, 26], has been described, although this effect of the drug is still disputed [27]. An increase in the number of beta cells could reduce the metabolic stress on individual cells, thereby delaying the onset of diabetes. The similarity in pancreatic insulin contents of the different treatment groups however, make this an unlikely explanation for the reduced incidence of diabetes in tolbutamide-treated animals.

Diet is a factor known to influence diabetes incidence in the NOD mouse [28]. No significant influence of diazoxide or tolbutamide treatment on body weight was observed however, indicating that changes in food intake are unlikely to explain the effects of these drugs on insulitis and diabetes.

In conclusion, the incidence of diabetes in NOD mice is reduced by prophylactic treatment with tolbutamide but not diazoxide. The reduction in diabetes incidence could not however, be related to alterations in the functional state of the beta cells. Elucidation of the precise mechanisms by which tolbutamide affords protection from diabetes in the NOD mouse, may clarify the sequence of events leading to Type 1 diabetes. This may be important when designing new therapeutic strategies for disease prevention during the pre-diabetic period.

Acknowledgements. This work was supported by grants from the Joint Research Board, St. Bartholomew's Hospital and the Italian Research Council (CNR) grant no.90.01530.CT04. We thank Ms H. Gillmor, Mr. K. J. Mansfield and Ms L. A. Burr for technical assistance, Ms J.Thomas for statistical advice and Dr. P. Bingley for help with the manuscript.

\section{References}

1. Gotfredsen CF, Buschard K, Frandsen EK (1985) Reduction of diabetes incidence of BB Wistar rats by early prophylactic insulin treatment of diabetes-prone animals. Diabetologia 28: 933-935

2. Like AA (1986) Insulin injections prevent diabetes in BioBreeding/Worcester rats. Diabetes 35 [Suppl 1]: 74A (Abstract)

3. Atkinson MA, MacLaren NK, Luchetta R (1990) Insulitis and diabetes in NOD mice reduced by prophylactic insulin therapy. Diabetes 39: 933-937

4. Shah SC, Malone JI, Simpson NE (1989) A randomized trial of intensive insulin therapy in newly diagnosed insulin-dependent diabetes mellitus. N Engl J Med 320: 550-554

5. International Diabetes Immunotherapy Group (IDIG) (1991) Ongoing immunotherapy trials reported to IDIG. Diabetes prevention therapy $5: 16$

6. Trube G, Rorsman P, Ohno-Shosaku T (1986) Opposite effects of tolbutamide and diazoxide on the ATP-dependent $\mathrm{K}+$ channel in mouse pancreatic beta cells. Pfleugers Arch 407:493-499

7. Williams AJK, Krug J, Beales PE, Procaccini E, Pozzilli P (1991) Tolbutamide, not diazoxide, reduces the incidence of diabetes in the non-obese diabetic (NOD) mouse. Diabetes 40 [Suppl 1]: 116A (Abstract)

8. Bingley PJ, Gale EAM (1991) Lessons from family studies. In: Harrison LC, Tait BD (eds) Clinical endocrinology and metabolism, Volume 5. Bailliere Tindall, London pp 261-284

9. Signore A, Pozzilli P, Gale EAM, Andreani D, Beverley PCL (1989) The natural history of lymphocyte subsets infiltrating the pancreas of NOD mice. Diabetologia 32: 282-289

10. Mansfield KJ, Beales PE, Williams AJK, Lampeter EF, Pozzilli P (1992) Housing, production and life-maintenance of the nonobese diabetic (NOD) mouse. Animal Technology 43: 29-37

11. Morgan DR, Lazarow A (1963) Immunoassay of insulin: two antibody system. Diabetes $20: 1-9$

12. Armitage P, Berry G (1987) Statistical methods in medical research, 2nd edn. Blackwell, Oxford, pp 429-433

13. Vlahos WD, Yale JF (1987) Prevention of type 1 diabetes in the $\mathrm{BB}$ rat by diazoxide. Clin Invest Med 10: B65 (Abstract)

14. Pontiroli AE, Alberetto M, Bertoletti A, Baio G, Pozza G (1984) Sulfonylureas enhance in vivo the effectiveness of insulin in type 1 (insulin-dependent) diabetes mellitus. Horm Metab Res 16 [Suppl 1]: 167-170

15. Pernet A, Trimble ER, Kuntschen F, Assal J-Ph, Hahn C, Renold AE (1985) Sulfonylureas in insulin-dependent (type 1) diabetes: evidence for an extrapancreatic effect in vivo. J Clin Endocrinol Metab 61:247-251 
16. Mooridan AD (1987) The effect of sulphonylurea on the in vivo uptake of glucose in normal rats. Diabetologia 30:120-121

17. Goto $Y$, Kaino $Y$, Inoue $T$, Ikeuchi $M$, Miyagawa $T$, Matsuda $H$ (1988) Insulin action on glucose uptake by soleus muscles of nonobese diabetic mice and streptozotocin diabetic mice. Metabolism 37:74 78

18. Gottlieb PA, Handler ES, Appel MC, Greiner DL, Mordes JP, Rossini AA (1991) Insulin treatment prevents diabetes mellitus but not thyroiditis in RT6-depleted diabetes resistant BB/Wor rats. Diabetologia 34: 296-300

19. Buschard K, Brogren C-H, Ropke C, Rygaard J (1988) Antigen expression of the pancreatic beta-cells is dependent on their functional state, as shown by a specific BB rat monoclonal autoantibody IC2. APMIS 96: 342-346

20. Zhang ZJ, Davidson L, Eisenbarth G, Weiner HL (1991) Suppression of diabetes in nonobese diabetic mice by oral administration of porcine insulin. Proc Natl Acad Sci USA 88: 1025210256

21. Chan E, Hosszufalusi N, Charles MA (1991) The use of glipizide to prevent diabetes in the BB rat. Diabetes 40 [Suppl 1]: 116A (Abstract)

22. Curry DL, Reaven G, Reaven E (1984) Glucose-induced insulin secretion by perfused pancreas of 2- and 12-mo-old Fischer 344 rats. Am J Physiol 247: E385-E388

23. Goidl EA, Innes JB, Weksler ME (1976) Immunological studies of aging II. Loss of IgG and high avidity plaque-forming cells and increased suppressor cell activity in aging mice. J Exp Med 144: 1037-1048
24. Bunnag SC, Warner NE, Bunnag S (1966) Effect of tolbutamide on postnatal neogenesis of the islet of Langerhans in mouse. Diabetes 15: 597-603

25. Chick WL (1973) Beta cell replication in rat pancreatic monolayer cultures: effects of glucose, tolbutamide, glucocorticoid, growth hormone and glucagon. Diabetes 22:687-693

26. Popiela H, Morre W (1991) Tolbutamide stimulates proliferation of pancreatic beta cells in culture. Pancreas 6: 464-469

27. Hellerstrom C, Swenne I (1985) Growth pattern of pancreatic islets in animals. In: Volk BW, Arquilla ER (eds) The diabetic pancreas, 2nd edn. Plenum Press, New York pp 53-79

28. Coleman DL, Kuzava JE, Leiter EH (1990) Effect of diet on incidence of diabetes in nonobese diabetic mice. Diabetes $39: 432$ 436

Received: 18 June 1992

and in final revised form: 20 January 1993

Dr. A.J.K. Williams

Department of Diabetes and Metabolism

St. Bartholomew's Hospital

West Smithfield

London EC1A 7BE

UK 